\title{
ADMINISTRATION OF INSURANCE RATE REGULATORY LAWS
}

\author{
Charles F. J. Harrington*
}

This brief discussion of the administration of rate regulatory laws contemplates that the reader will be to some extent familiar with the historical and factual background which led to the action against the South-Eastern Underwriters Association and the series of events which followed. Such a discussion is beyond the confines of time and space of this paper. The events to which I refer are the decision of the United States Supreme Court in United States v. South-Eastern Underwriters Association; ${ }^{1}$ the activities of the Sub-Committee on Federal Legislation of the National Association of Insurance Commissioners and the Executive Committee of that organization; ${ }^{2}$ the enactment of the McCarran Act; ${ }^{2 n}$ the activities of the AllIndustry Committee; ${ }^{3}$ a cursory knowledge of the model rate regulatory bills submitted to the National Association of Insurance Commissioners with explanatory memoranda, together with reports of the Committee on Rates and Rating Organizations and Federal Legislation of the National Association of Insurance Commissioners and the concurrent report of the All-Industry Committee; ${ }^{4}$ and some of the differences in the rating laws enacted by the several states. ${ }^{5}$

A review of the history and background which led the insurance.industry to seek governmental regulation of its economic "bloodstream," the premium dollar, will indicate clearly that the nature and extent of the regulation to be sought was not free from controversy. ${ }^{6}$ Hence there is little wonder that the rating laws recently enacted in the several states should differ, but it is remarkable that practically. all states have adopted a substantial part of the model bills approved by the National Association of Insurance Commissioners.

"The prime purpose of all rate (or other) regulation is protection of the buyer of insurance and through him the general public who pays his costs, hence the generally

- LL.B. I939, Suffolk University Law School. Director of the Insurance Society of Massachusetts. Past President of the National Association of Insurance Commissioners. Commissioner of Insurance for the Commonwealth of Massachusetts, since 1938 .

1322 U. S. 533 (1944).

${ }^{2}$ Legislative proposal submitted to the Congress of the United States by Executive Committee of the National Association of Insurance Commissioners, November, r944.

Report of the Joint Committees on Rate and Rating Organizations and Federal Legislation of the National Association of Insurance Commissioners. Proceedings of the Natjonat Ass'n of Insurance Commissioners (June, I944-June, 1947).

2a 59 STAT. 33 (1945), I5 U. S. C. §§IOII-ToI5 (1946).

3 Paper by James B. Donovan, which appears elsewhere in this symposium.

* Proceedings, N. A. I. C. $353,355-422$ (1946).

- Address by Ray Murphy delivered before the Insurance Section, American Bar Association, at Cleveland, Ohio, December 22, I947.

- Procendings, N. A. I. C. 355, 356 (1946); State Regulation of Casualty Insurance Rates, Memorandum by the Special Committee on Legislation of the American Mutual Alliance in II Characteristics of Effective State Rate Regulation 8-ri (x947); Fourth and Fifth Reports of Sub-Committee of LAwyers to the CoMnittee on LAws of the Natjonal BoArd of Fire UNDERwriters Pursuant to Resolution Adopted at May 9, 1945 Meetting of the Comaittee on Laws (1945). 
accepted formula that rates shall be adequate, reasonable, and not unfairly discriminatory." This formula is included in all rate regulatory laws.

Most of the state laws which follow the form of the model bills go beyond the mere recitation of a formula or standards to be observed with respect to the supervision of rates. They set forth at some length that rates shall be made in accordance with a number of enumerated provisions. ${ }^{8}$ There are varying points of view concerning the administration of these sections. One point of view with which there is not complete agreement is contained in the memorandum prepared by the Committee on Legislation of the American Mutual Alliance, November, 1947, entitled, "State Regulation of Casualty Insurance Rates." Incidentally, this memorandum is a comprehensive and erudite discussion of the problem from the point of view of a large segment of the insurance industry.

The extent to which these standards will be appropriately applied rests upon the frailty of human judgment interpreting the language and following all of the legislative provisions prescribed, according to which rates shall be made. It further depends upon the training and ability of those charged with the responsibility of administering the rate regulatory law. "The statutes which the tribunal (Commissioner) administers should be well, simply, and carefully framed, but the personnel which does the administering is more important than the wording of the statute. Good men can produce better results with a poor law than poor men can produce with a good law."10

We have passed the stage involving the preparation of rate regulatory statutes. The model laws approved by the National Association of Insurance Commissioners were produced by talented lawyers skilled in the drafting of legislation. Those draftsmen were advised by underwriters, actuaries, public officials, and technicians familiar with the conduct of the business of insurance. "In the course of the conferences many conflicting views among many segments of the industry, as well as between the industry and the commissioners, were reconciled and these bills can be viewed as representing the composite views of those who participated in the deliberations." ${ }^{11}$ These rating laws have been well and carefully framed. It is improbable they will be amended until a reasonable opportunity has been afforded to test their practical operation and to determine any imperfections which may impair smooth administration in the interest of the public. Of course there should be no delay in promptly offering amendments to rating laws when it is discovered that amendments are necessary or desirable.

The importance of a well-trained staff to deal with technical actuarial and mathematical problems cannot be overstated. As a matter of fact, it has been urged by

\footnotetext{
'Address of Professor Ralph H. Blanchard of Columbia University before the Fire and Casualty Insurance Conference, April 30, r945.

${ }^{8}$ Mass. Gen. Laws, c. I74A, I75A, \$5.

- State Regulation of Casualty Insurance Rates, 9-14 (Memorandum prepared by Committec on Legislation of the American Mutual Alliance, November, 1947).

${ }_{10} \mathrm{~A}$ "Credo" as to the Judicial Functions of Administratite Tribunals, 30 A. B. A. J. 266, 267 (1944).

${ }^{12}$ Proceedings, N. A. I. C. 377 (I946).
} 
representative segments of the industry that the selection of an insurance commissioner "should only be made with regard for the appointee's experience and qualifications" and that "the work of an Insurance Department should be undertaken only by full-time qualified employees whose pay is sufficient to make them conscious of their responsibilities and free from insurance company or political influence."12 Many states have followed this suggestion with respect to the personnel of the Department and in some instances with respect to the appointment of the commissioner. As the development of rate regulatory procedures progresses, the wisdom of these suggestions may be more fully appraised.

It is naive to expect that the administration of rating laws will always be free from controversy between the industry and the insurance commissioner. As a matter of fact, difference of opinion should be expected to some extent if the states are affirmatively facing their responsibilities. Controversy does not always flow from differences of opinion between the commissioner and the industry, it frequently arises because of differences of opinion within the industry itself with respect to rates and rating methods. ${ }^{13}$ Such controversy, however, should be resolved wherever possible through conference and negotiation rather than by judicial determination. The application of the strict rules of evidence required in court cases frequently circumscribes the practical determination of the merits of a particular rate filing. Frequently rate litigation turns upon technical and procedural points rather than upon the merits of the case. ${ }^{14}$

"One of the dangers of regulation by the state as well as by company bureaus is that of rigidity."15 While laws once enacted are difficult to revise, regulatory practices are less difficult to change, although changes of regulatory personnel are conducive to adherence to precedent, particularly during the training period of a commissioner or his staff. I would be unfair if I did not recognize that some administrators are also sticklers for precedent, although I have rarely met an insurance commissioner who is not willing to give full and reasonable consideration to a well-presented and well-argued case for a change. It should be remembered, however, that it is the duty of the rate administrator to pass upon the evidence presented to him and to be guided by it-hence the virtue of the informal administrative conference compared with the formal type of hearing.

Where the insurance commissioner and the rating bureau are the only parties to a controversy, reconciliation of the areas of disagreement can usually be accomplished by negotiation and compromise. Less frequently controversy involving other parties may be similarly resolved. However, in cases where it is mandatory for a hearing to be held before the commissioner may act, the problem assumes a different and more difficult aspect. If the law prescribes a hearing before the commissioner may

${ }^{12}$ State Regulation of Casualty Insurance Rates, op. cit. supra note 9, at 37.

${ }^{13}$ Proceedings before the New York Insurance Department relative to the "Escott Plan."

I4 American Employers' Insurance Co. v. Commissioner of Insurance, 298 Mass. 16r, Io N. E. $2 \mathrm{~d}$ 76 (1937).

${ }^{15}$ Address of Professor Ralph H. Blanchard before the Fire and Casualty Insurance Conference, April 30,1945 . 
act, "the provision for a hearing implies both the privilege of introducing evidence and the duty of deciding in accordance with it. To refuse to consider evidence introduced or to make an essential finding without supporting evidence is arbitrary action." "There must be evidence adequate to support pertinent and necessary findings of fact. Nothing can be treated as evidence which is not introduced as such.... The 'hearing' is designed to afford the safeguard that the one who decides shall be bound in good conscience to consider the evidence, to be guided by that alone, and to reach his conclusion uninfluenced by extraneous considerations which in other fields might have play in determining purely executive action. The 'hearing' is the hearing of evidence and argument."17

The foregoing discussion evidences the heavy responsibility imposed on the commissioner when conducting a hearing, particularly when adversaries are involved. It should not be inferred from this discussion that I contend administration of the rating law will always involve adversary proceedings. Usually such a situation should be the exception rather than the rule. Whenever formal hearings are prescribed by statute, not only is the commissioner obligated to conduct appropriate proceedings, but others who are involved are required to conform to procedure conducive to an adequate record.

The importance of a complete and accurate record of the proceedings before the commissioner is self-evident when we consider that all rate regulatory laws provide for judicial review of the actions of the commissioner. It is highly important that the record be as lucid and free from confusion as possible. The responsibility for a clear, well-presented case rests upon all of the parties to the hearing, but to a greater extent upon the hearing officer. While no rating law requires the observance of the strict rules of evidence by the hearing officer, he is duty bound to adopt reasonable rules and regulations for orderly conduct of the hearing.

Today, more than ever before, harmonious, flexible administration of rating laws is necessary because of the widespread adoption of rating laws by the several states. Flexibility of administration does not mean that the commissioner may totally disregard the law, he is merely the executive officer of the legislature charged with the responsibility of carrying out the legislative command. Where difference of opinion with respect to the interpretation of law arises, it is the decision of the commissioner which prevails until altered by the opinion of the attorney general or other legal adviser to the commissioner, or by the court.

Laws which confer discretionary authority upon the commissioner of insurance are much more easily administered than laws which attempt with particularity to chart the course which the commissioner must follow. It should be recognized that there is a difference in administrative procedures depending upon the legislative philosophy with respect to the nature and extent of rate regulation. Under a rate

\footnotetext{
${ }^{10}$ American Employers' Insurance Co. v. Commissioner of Insurance, 298 Mass. 16r, 167, ro N. E. 2d 76,80 (1937).

${ }^{17}$ Morgan v. United States, 298 U. S. 468,480 (1936), referred to in the American Employers' Insurance Co. v. Commissioner of Insurance, 298 Mass. r61, 167, 168, 10 N. E. 2d 76, 80 (1937).
} 
regulatory law which imposes upon the commissioner the obligation to make the rates, as in Texas or in Massachusetts under the Compulsory Motor Vehicle Liability Law, ${ }^{18}$ the practice has been to confer and consult with those who have available material and ideas with respect to the calculation of rates and to give due consideration to their views before promulgating rates. The decision with respect to the final determination of the rates rests entirely in the wide but reasonable discretion of the commissioner. The commissioner of insurance charged with the making of rates enjoys a wider opportunity for the exercise of discretion in his rate making processes, but he likewise bears a heavy responsibility to make rates in accordance with sound actuarial principles which meet the standards prescribed by the legislature.

The type of law which requires the prior approval of rates before they may be used is the type of law usually governing the regulation of workmen's compensation rates. This type of law calls for a different administrative procedure. It requires, in the first instance, that the commissioner shall act promptly upon rate filings placed before him for action, but it also requires a careful examination of the basis upon which the rates are made, including the volume and quality of the statistical material underlying the calculation of the rates. In many states the commissioner is not privileged to confer with the rating bureau committees prior to the submission of rates for his consideration. When these limitations are imposed upon the rate supervisor it must be expected that a longer period will be consumed in acquainting the commissioner with the considerations, formulae, and statistics which have occupied the attention of the rating bureau or insurance company for many months in advance of the filing. Delay can be very materially reduced if the commissioner or his representative is permitted to participate in the meetings of the various committees of the rating bureau while they are developing rate making processes. I realize that the rating laws do not contemplate the procedure here outlined, but I submit that much benefit inures to both the supervised and the supervisor when problems are approached in this fashion.

The third regulatory procedure is the so-called filing and use procedure which permits an insurance company to file rates and use them immediately without opportunity for the commissioner to review the rate calculations in advance and approve or disapprove. There are those who believe that this does not constitute regulation contemplated by the Congress under the provisions of the $\mathrm{McCarran} \mathrm{Act.}{ }^{19}$ On the other hand the Lawyers Committee of the National Board of Fire Underwriters states, "We feel, however, that in judging the regulatory system as a whole,

${ }^{28}$ MAss. GEN. LAws, c. I75, $\$ \mathrm{Ir}_{3} \mathrm{~B}$.

${ }^{10}$ See testimony of Attorney General Biddle in Joint Hearings before the Sub-Committees of the Committees on the Iudiciary on $S$. ${ }_{3362}$, Pt. 6, 78th Cong., 2d Sess. 638 (1944). "Therefore the large number of State acts which simply permit rate bureaus to fix rates do very definitely come in conflict with the Fcderal law. There are only very few States, Texas notably, which fix their rates; and it seems to me that if the States wish to be free of the compulsion of the antitrust law that they must take a responsibility of actually fixing the rates or approving the rates filed with them, because I cannot see otherwise how the public is protected." 
a great deal of importance should be attached to the matter of filing, since filing places the commissioner in a better position to pass judgment on the rates and to exercise his powers of control. Even if a State should determine that a requirement of filing is not appropriate in all cases, it might be advisable for it to combine methods Nos. 3 and 4, by requiring filing with power in the commissioner to waive filings in certain classes, or requiring filing only in certain classes, with power in the commissioner to require filing in other classes." ${ }^{20}$ The validity of a filing and use law appears to be accepted generally by the industry, since neither stock nor mutual companies acting in concert under the provisions of Chapter $174 \mathrm{~A}$ and $175 \mathrm{~A}$ of the General Laws of the Commonwealth of Massachusetts seem inclined to challenge the validity of this law. From the standpoint of the public, the law has one frailtyit contains no provision for the return of premiums which have been adjudged excessive by the commissioner of insurance or the courts. The decision of the commissioner applies only to contracts made on and after the effective date of his decision.

The problem of coordinating the regulatory activities of the several states, particularly as they pertain to the regulation of rates computed on a national basis as well as rates which must be predicated upon national experience because of the limited volume of experience within a single state, still calls for solution. The Honorable Chris A. Gough, who, among all the commissioners, has served more than fifty years in the field of insurance supervision, strongly advocates the development of a cooperative program administered by a salaried technical staff employed by the National Association of Insurance Commissioners and operating under the direction of the Committee on Rates and Rating Organizations. A program of this nature would be likely to produce adequate supervision of interstate rate levels and minimize, if not eliminate, conflicts between states with respect to the regulation of rates. The model rate regulatory bills adopted by the National Association of Insurance Commissioners were designed to permit uniform administration of rate regulatory laws by authorizing the commissioner, insurance companies, and rating organizations to exchange information and experience data, and permit insurance supervisory officials to consult and cooperate with respect to rate making and the approval of rating systems under reasonable rules and regulations necessary to effect the purposes of the rating laws. ${ }^{21}$

The insurance industry and the commissioners should immediately seek the removal of barriers, if any, which prevent satisfaction of the public demand for insurance policies providing comprehensive insurance protection (combination fire and casualty policies). The reasonable requirements of the insuring public should not remain unsatisfied because the mechanics of the insurance business has not kept

\footnotetext{
${ }^{20}$ Fourth and Fifth Reports of the Sub-Commttee of Lawyers to the Committee on Laws of the National Board of Fire Underwriters Pursuant to Resolution Adopted at May 9, I945 Meeting of the Comauttee on Latws II, 12 (I945).

${ }^{21}$ Mass. GeN. Laws, c. $174 \mathrm{~A}, \S \mathrm{I5}_{5}(\mathrm{~b})$, (c) and (d), $175 \mathrm{~A}, \S \mathrm{I5}_{5}(\mathrm{~b}),(\mathrm{c})$ and (d). (The language of the portions of the sections cited is identical with the language of the model bills approved by the N. A. I. C. This language is included in nearly all of the rate regulatory laws.)
} 
pace with the demands of our ever changing economy. Administrative difficulties arise in connection with the supervision of rating programs which involve fire, casualty, and marine insurance protection because of the conflicting jurisdiction and limitations on the scope of authority of rating bureaus and advisory organizations. This problem has been the subject of comment recently by Robert E. Dineen, former Superintendent of Insurance of New York. ${ }^{22}$

Discussion within the industry manifests a realization of the necessity for exploration or revision of jurisdiction ${ }^{23}$ of both casualty and fire insurance rating bureaus. The establishment of a bureau through which comprehensive multiple line coverages may be developed and rated is a progressive step the industry can take in the interest of better rate regulatory administration. There appears to be no specific authority in the insurance law to enable the commissioners of insurance to bring about the necessary bureau changes at this time, hence the responsibility for progress in this direction rests heavily upon the leaders of the insurance industry.

An impediment to the early development of all-risk coverage is the statutory fire insurance policy, ${ }^{24}$ which prescribes in many states the exact, inflexible language of the policy which must be issued to cover fire insurance hazards. Whatever may have been the reason for incorporating only this form of policy in the laws of the several states, I can think of no reason which justifies the continuance in the statute of one particular form of insurance policy. It is inconceivable that the Legislature and insurance companies should impose inflexible, outmoded, and archaic insurance contracts upon the insuring public. We who are concerned with the regulation of the insurance business should give consideration to the rapidity with which our modern economy changes and to the removal of legal impediments to the issuance of modern insurance policies. ${ }^{25}$ It is difficult to understand the lack of support in the fire insurance industry for the repeal of archaic, outmoded, legislative requirements for standard policies. I should prefer to see the Standard Fire Policy provisions totally repealed in every state. I realize that this thinking is too drastic to receive current support, hence the reason for my legislative approach to the problem this year. ${ }^{26}$ Experience indicates the industry is not yet ready to accept this solution. "The development of a comprehensive all-risk policy, and particularly if on a single-rate basis, will inevitably come slowly."2T

The development of dwelling all-risk supplemental contracts; provision for legal liability insurance, fire and casualty; deviations and separate filings; and multiple

\footnotetext{
22 "Battle of the Burcaus," address of Robert E. Dineen, delivered before the New York State Agents, Inc., Syracuse, New York, May 8, r950.

${ }^{23}$ Address of Harold Smith, President, The Home Insurance Company, before Association of Local Agents of New York State, April 27, 1950.

${ }^{24}$ Mass. Gen. LAws, c. I75, \$99. Similar sections, although varying in language, are incorporated in the laws of other states.

25 I950 House Bill 66, Massachusetts Legislature.

20 y950 House Bill 68, Massachusetts Legislature.

${ }^{27}$ Presidential address, James M. Cahill, Secretary to the National Bureau of Casualty Underwriters beforc the Casualty Actuarial Society, November 2I, 1949.
} 
line operations are all receiving the current consideration of the Eastern Underwriters Association. ${ }^{28}$

It appears, however, from the unanimous action of the membership of the Eastern Underwriters Association at a recent meeting that the question of the inclusion of deductible clauses in fire insurance policies is stalled, if not negatively determined, for the time being in the territory served by that Association excepting as these clauses may be filed by companies not members of that Association. ${ }^{20}$ The rapidity with which company views change is indicated by the fact that since the meeting of the Eastern Underwriters Association on June 20, attended by the Fireman's Fund Insurance Company, the president of that company is reported to have decided that his company "will consider legitimate requests for deductible fire insurance risks in California." 30 Is it to be inferred that deductible clauses in fire insurance would not be "destructive of the experience statistics so necessary for determination of adequate, reasonable, and nondiscriminatory rate levels" in the State of California?

Since much of the responsibility of solving most of these problems rests with the insurance industry, a joint meeting of the top-flight fire and casualty executives clothed with authority to negotiate with the Committee on Rates and Rating Organizations of the National Association of Insurance Commissioners would probably go far toward resolving the present stalemate on some of these important problems. I mention this matter with no disposition to be critical, but because it is an important problem not only from the standpoint of the insurance industry and the supervisors of insurance, but from the standpoint of the insurance buying public.

The administration of rating laws regulating all classes of insurance rates other than life insurance and marine insurance is in its infancy in many states. The regulation of many rate levels is being undertaken for the first time by experienced insurance departments. Very few commissioners remain who are familiar with all of the activities of the Committee on Rates and Rating Organizations and the All-Industry Committee. Administrative procedures regulating rates are also in their infancy. The bridle and saddle of rate regulation still irritate the insurance industry which is not thoroughly broken and accustomed to the obligations and

${ }^{28}$ Proceedings of the Eastern Underwriters Association Mreting 2425, 2426, 2427, 2428 (June 20, 1950).

${ }_{20}$ Proceedings of the Eastern Underwruters Association Meeting 2427 (June 20, 1950). "The following resolution is recommended by the Executive Committee to the membership: After a thorough discussion of the subject matter of Deductibles in Fire Insurance, it is Resolved by the membership of the Eastern Underwriters Association that Deductible Clauses in Fire Insurance would be destructive of the experience statistics so necessary for the determination of adequate, reasonable and non-discriminatory rate levels and that for that and other reasons, Deductible Clauses in Fire Insurance are not in the best interest of the insuring public - or the Fire Insurance Industry, and that the Rating Methods Research Committce of this Association be advised of the viewpoint of the membership on the subject matter. On Motion, the Resolution was Unanimously Adopted."

30 "Beginning immediately, we will consider legitimate requests for deductible fire insurance risks in California to the extent of our capacity and such reinsurance as we can secure, providing adequate premiums are obtainable. This step should prove useful to those in the production ranks who presently suffer through a lack of a domestic insurer's market." James F. Crafts, President of Fireman's Fund, in The Standard, July 14, 1950, p. 13. 
restraints of total rate regulation. When we consider that cooperation between the insurance industry and the National Association of Insurance Commissioners has produced outstanding accomplishments in procuring the passage of rate regulatory laws with a legislative command that they be liberally interpreted, it should be apparent that with continued cooperation and a continued devotion to a solution of the regulatory problems flowing from the enactment of the legislation the business of insurance will be able to continue to serve the people of America in a satisfactory manner. 